Vasko G. Fotev
Associate Professor
University of Belgrade
Faculty of Mechanical Engineering
Mirko Dinulović
Associate Professor
University of Belgrade

\section{Heat Transfer and Thermo-mechanical Behavior of the Domestic Heater Atmospheric Burner}

This paper presents performed 3D CFD simulation of burner start-up and finding the maximal temperature difference through mantle thickness which induces maximal thermal stress. The process is unsteady, beginning from the mantle room temperature and ending with its steady state condition. The behavior of burner is simulated for minimal thermal power, i.e., for critical conditions from the mantle temperature standpoint.

Keywords: atmospheric burner, combustion, CFD, simulation

\section{INTRODUCTION}

Gas heaters, as domestic appliances are in wide use. Because of that the emission of $\mathrm{CO}$ and NOx has to be decreased [1]. Old burners, which works in fuel reach zone are stable in broad power range (from 1 to $10 \mathrm{~kW}$ of thermal power), but they are high pollution devices. For that reason, the emission is limited to $50 \mathrm{mg} / \mathrm{kWh}$ for $\mathrm{CO}$ and NOx. This goal may be reached by new developed burners working in fuel lean conditions. This task is connected with natural combustion instability, small turn down ratio and high sensitivity on fuel (gas) quality [2-5]. Design procedure for lean gas burners is much more complicated, and needs much more powerful design tools. One of that is CFD modelling [67]. Nowadays commercial software, as FLUENT, is available even for ordinary PC computer. This paper presents on of design stages in which CFD modelling is implemented. Unsteady heat transfer to the burner, from the moment when heater is turned on, gives a lot of data needed for other design stages as: thermo mechanical stress strain, thermal fatigue, heater automatic control, burner lifetime, etc.

\section{DOMESTIC GAS HEATER}

The outlook of domestic gas heater is presented in fig.1. The appliance is supplied with natural gas or with propane butane. It is fully independent and can work with gas from tank. Thermal power is from 1.3 to 10 $\mathrm{kW}$.

Room temperature control is adjusted by hand power positioning button (gas pressure drop valve), and by automatically burner turning on and off by thermostat. This introduces high number of on/off cycles which leads to burner material thermal fatigue.

In fig. 2 is presented burner cross section. The air entrainment is produset by fuel which enters Venturi tube, and lowers the pressure in its enter.

Received: June 2016, Accepted: July 2016

Correspondence to: Dr Vasko Fotev

Faculty of Mechanical Engineering,

Kraljice Marije 16, 11120 Belgrade 35, Serbia

E-mail: vfotev@mas.bg.ac.rs

doi:10.5937/fmet1701065F

(C) Faculty of Mechanical Engineering, Belgrade. All rights reserved

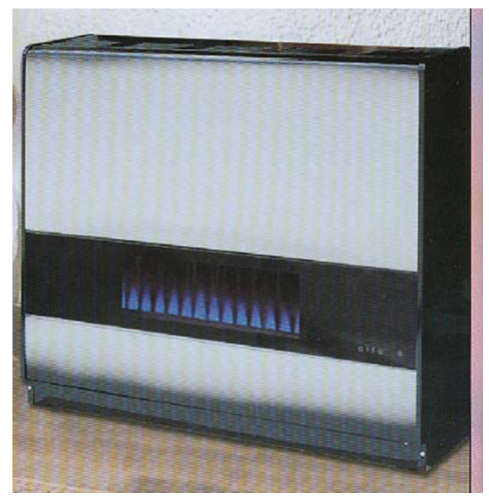

Figure 1. Domestic gas heater.

In Venturi tube there is mixing of air and fuel. The mixture exits the burner through the flame openings (radial lines in fig. 2.) and starts to burn. There is intensive heat transferee from the combustion zone to the burner surface. On the lower powers the distance between the flame and burner is minimal, so its thermal stress is maximal.

- exp. with air entrainment:

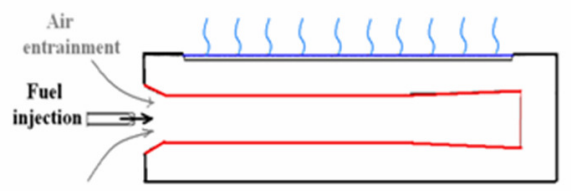

Figure 2. Gas burner with ejector.

\section{CFD MODEL}

CFD model is prepared starting from CAD model which is imported into the GAMBIT program for creating the mesh. Than the model is imported in FLUENT which is used for all simulations [8].

The model is unsteady. Turbulent model is $\mathrm{k}-\varepsilon$, for all fluid flow zones. Real chemical reaction is reduced on two reactions [9]. Fluid is ideal, incompressible gas with thermal and transport characteristics dependant from gas constitution $\left(\mathrm{C}_{3} \mathrm{H}_{8} \mathrm{O}_{2} \mathrm{CO}_{2} \mathrm{CO} \mathrm{H} 2 \mathrm{O} \mathrm{N} \mathrm{N}_{2}\right)$ and temperature. Combustion is volumetric reaction, finite rate. Solver is pressure based, SIMPLE pressure velocity coupling. Discretization is second order upwind. 
In the fig. 3 are presented geometry, boundary conditions and mesh. Burner mantle thickness is $0.6 \mathrm{~mm}$ and it is represented as solid with 6 elements over its thickness. Material is steel.

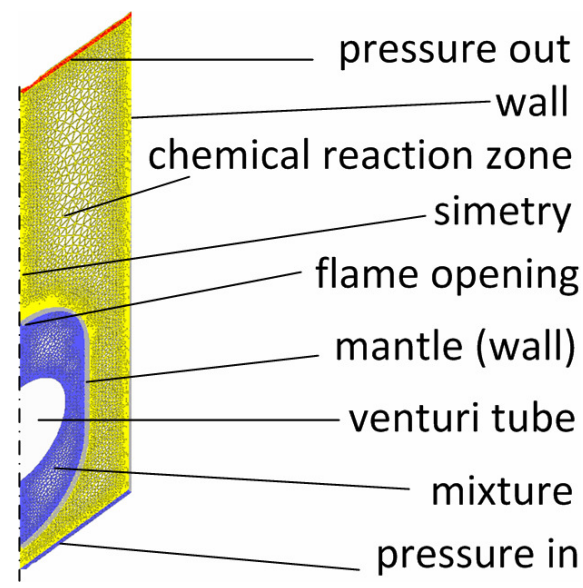

Figure 3. 3D burner slice.

Air fuel mixture flows into the chemical reaction zone through the flame openings. Their dimensions are partially defined by quenching effect, so that, in normal working conditions, there is no possibility for flame flashback.

\section{RESULTS OF SIMULATION}

Performed simulation of burner start-up is aimed to find mantle temperature field which includes thermal stress and shape changing which leads to thermal fatigue. Working condition for which burner is modelled are:

- $\quad$ Fuel $\mathrm{C}_{3} \mathrm{H}_{8}$

- Ar-fuel ratio 1.3

- Pressure drop at flame opening $0.6 \mathrm{~Pa}$

- Initial mantle temperature $288 \mathrm{~K}$

- Heat transferred by conduction and convection without radiation

- Thermal power $1.3 \mathrm{~kW}$

The process is unsteady, beginning from the mantle room temperature and ending with its steady thermal state conditions for given pressure drop at the mantle slots (flame openings). The behaviour of the burner is simulated for its minimal thermal power, i.e., for critical conditions from mantle temperature standpoint.

The obtained results of mantle surface temperature distribution are given in fig. 4 to fig 7 .

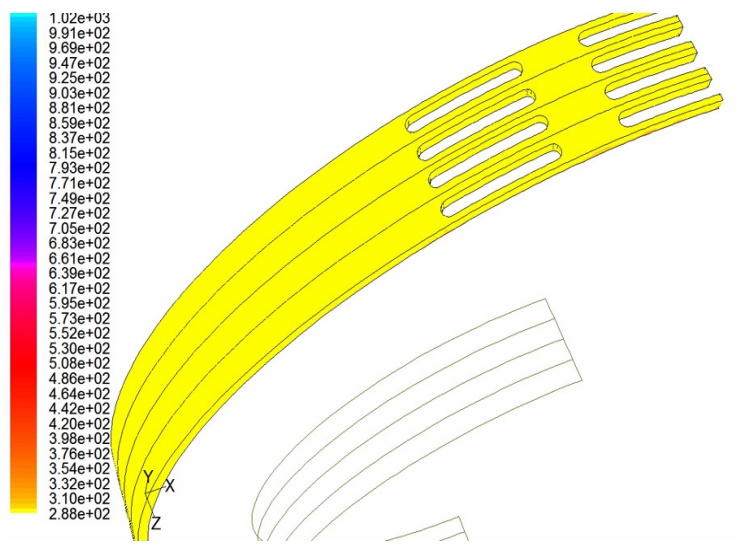

Figure 4. Burner surface temperature distribution $t=0 \mathrm{~s}$.
Temperature has maximal values in reggion where flame is close to mantle surface.

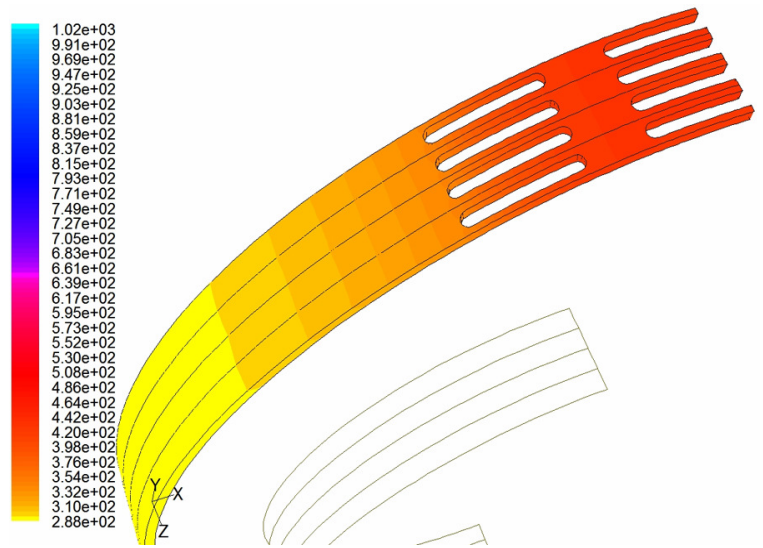

Figure 5. Burner surface temperature distribution $t=40 \mathrm{~s}$.

Generally, it can bee seen that the mantle maximal temperature is in the zone close to slots (flame openings)

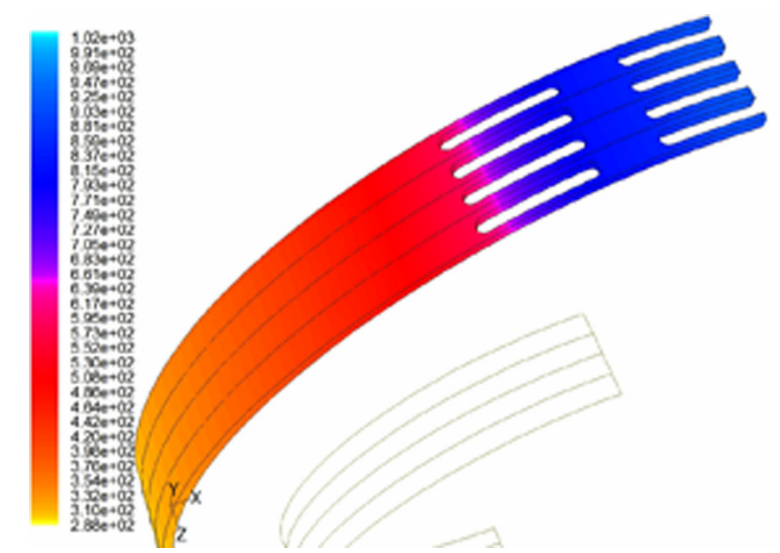

Figure 6. Burner surface temperature distribution $t=170 \mathrm{~s}$.

Because of the non-uniform temperature field of the mantle, thermal stresses are being induced.

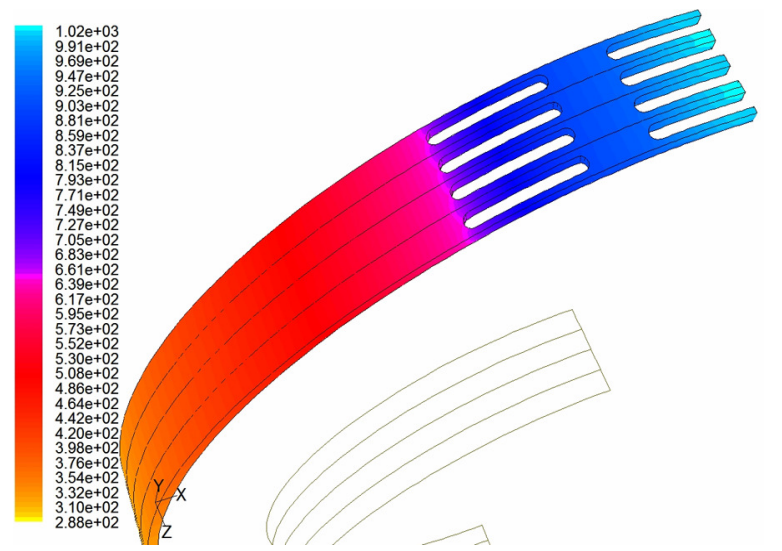

Figure 7. Burner surface temperature distribution $t=1800 \mathrm{~s}$.

Performed simulation indicates that the rapid burner heating is in the first 200 seconds (fig. 8), suggesting that this could be used as a measure of mantle temperature time lag.

On the other hand, the simulation have shown that the case when the burner is supplied with the mixture at constant pressure its power is decreased, due to decreases of mixture density. This mechanism is presented in the figures 9-12. 


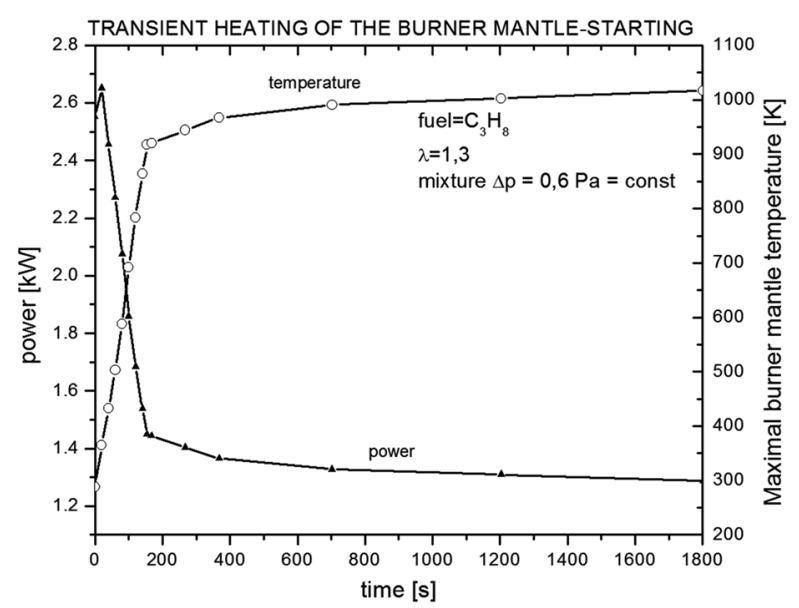

Figure 8. Burner surface temperature and power as function of time.

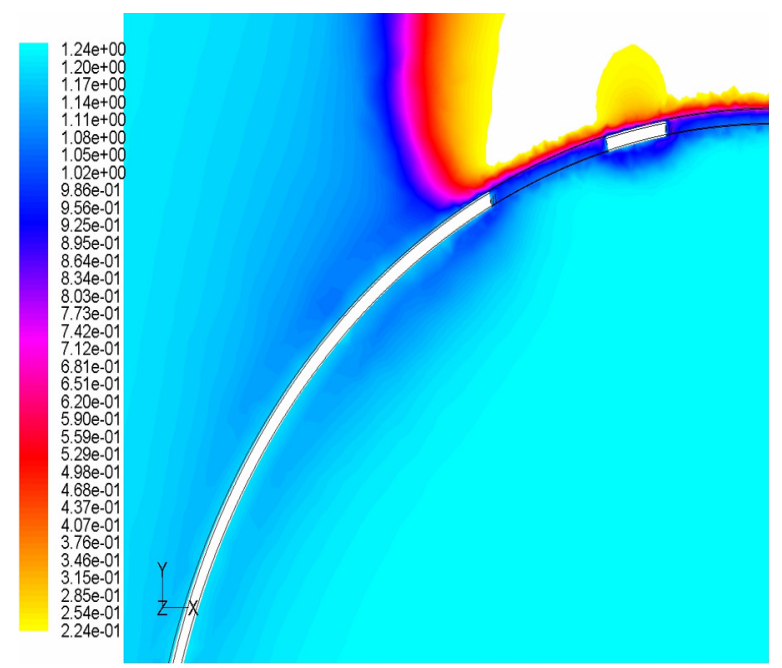

Figure 9. Field of gas density $\mathrm{t}=0 \mathrm{~s}$.

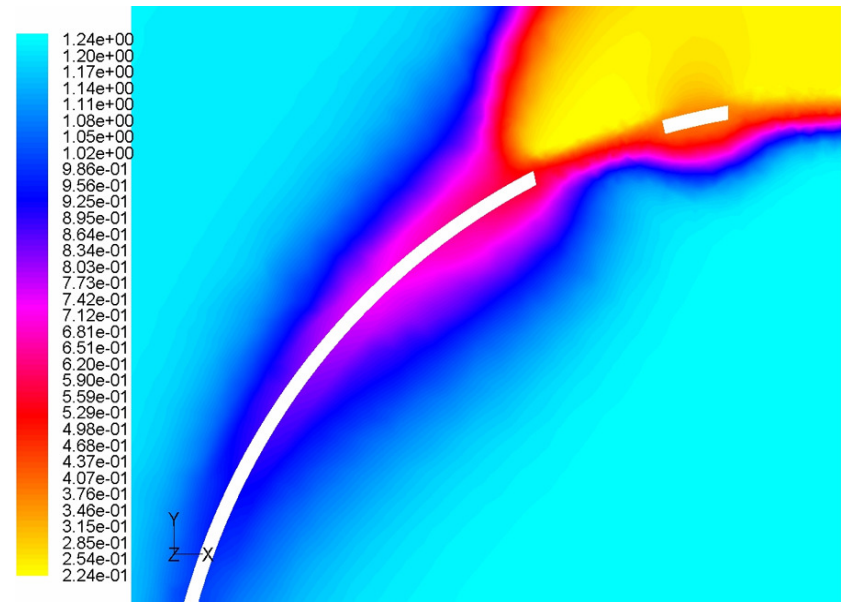

Figure 10. Field of gas density $t=1800 \mathrm{~s}$.

When burner reaches its steady state thermal conditions the heat transfer from combustion zone to the fresh mixture zone (close to mantle flame openings) is so intense that rises mixture temperature and decreases its density. Because of that it changes flow velocity, presented in figs. 11 and 12 .

This behaviour is reason why power is on start almost 2 times bigger than nominal settled (fig. 8).

Experimental validation of the CFD simulation has been performed by mantle colour. In fig. 13 is presented both mantle surface temperature fields. On the left side is calculated by CFD simulation. In the middle is mantle photo. On the right side is standard pyrometer colour temperature bar. In this fig. the colours are reversed because of visual clarity.

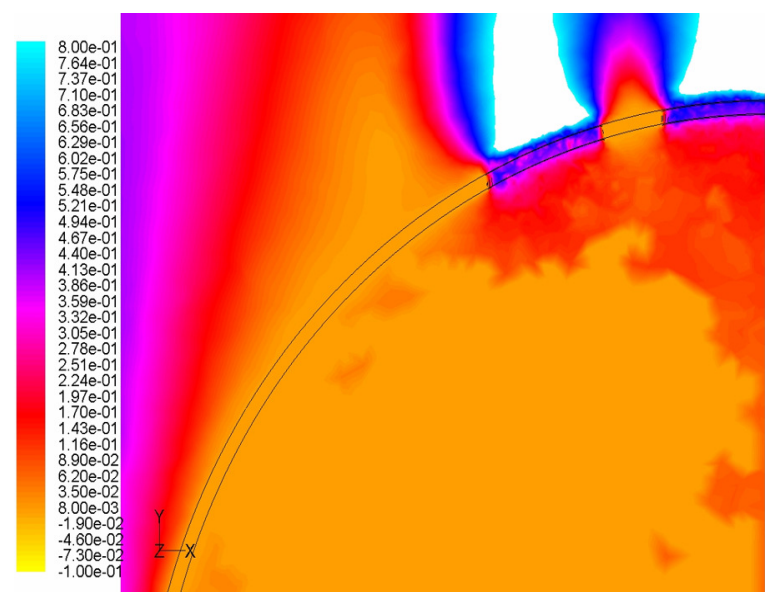

Figure 11. Field of gas $\mathrm{Y}$ velocity $\mathrm{t}=0 \mathrm{~s}$.

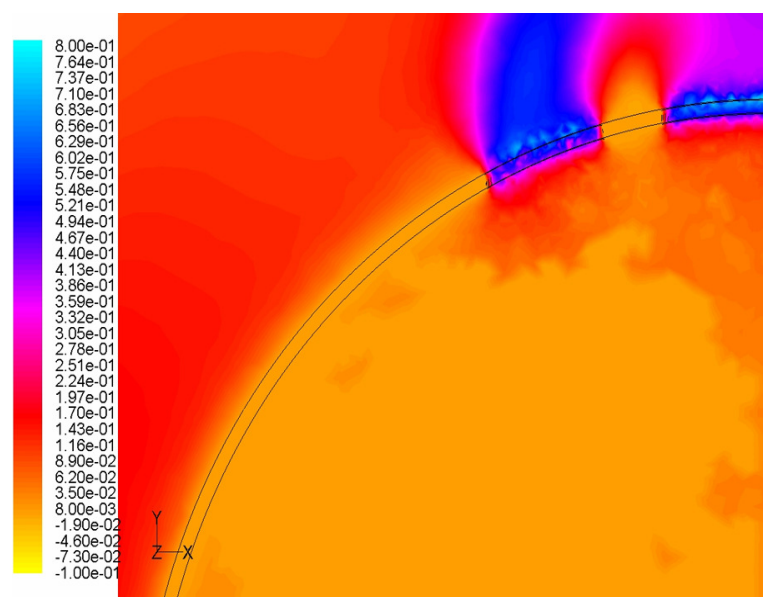

Figure 12. Field of gas $\mathrm{Y}$ velocity $\mathrm{t}=1800 \mathrm{~s}$.

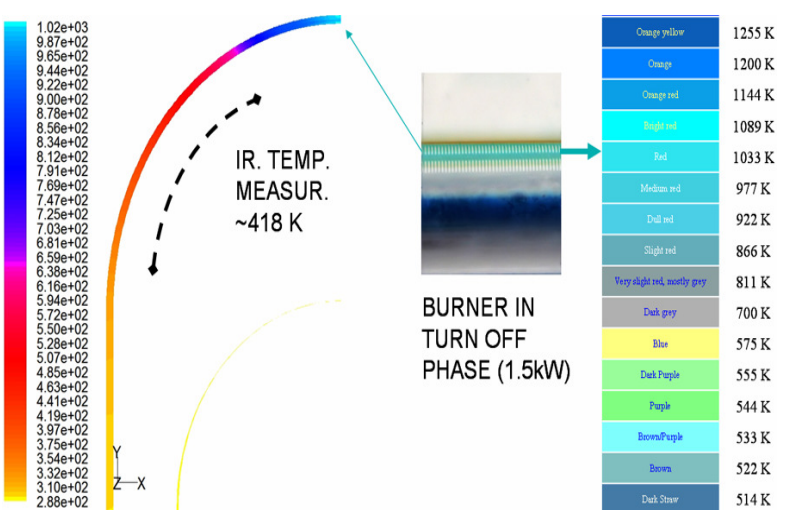

Figure 13. CFD modelled and real burner temperature field for stationary regime $t>1800 \mathrm{~s}$.

\section{CONCLUSION}

Mantle temperature field has been analysed and has provided that maximal temperature difference through mantle thickness occurs at the first second after ignition, presented in figs. 14 and 15 .

The maximal temperature difference is $5 \mathrm{~K}$. This temperature difference is too low to induce high mantle stress-strain conditions. This simulation disapproves our 
hypotesis that the ignition period may induce high stresses via high heat blast from the top side of the mantle.

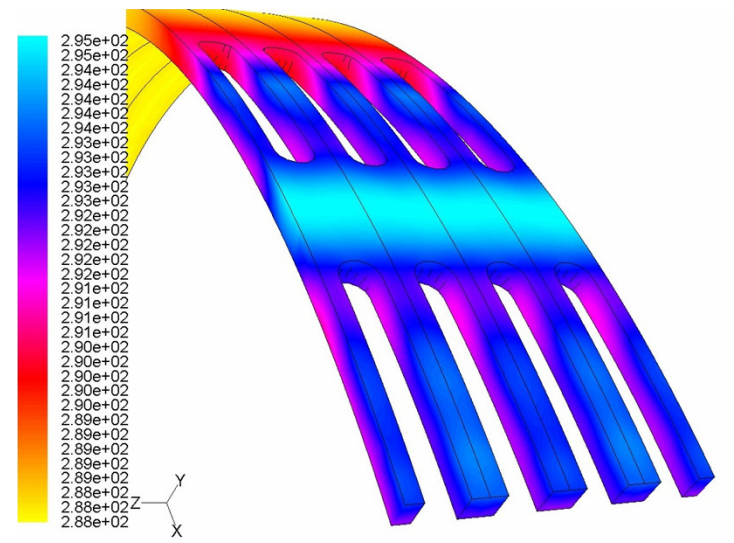

Figure 14. Burner surface temperature distribution $t=1 \mathrm{~s}$.

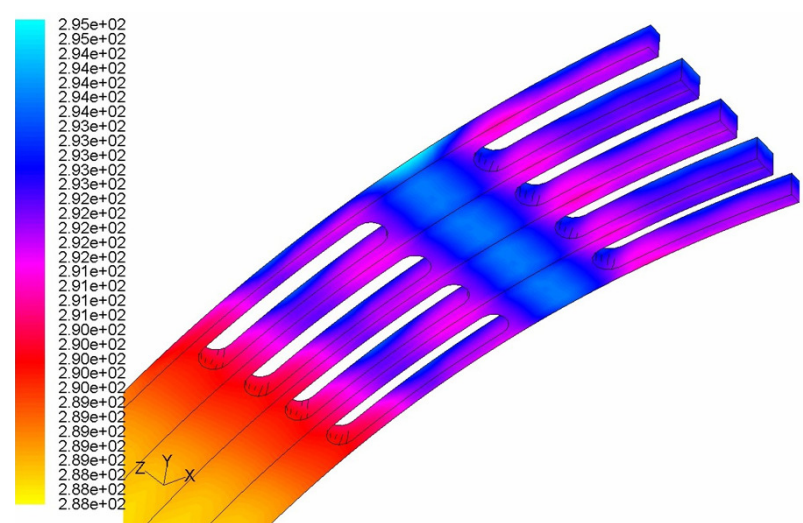

Figure 15. Burner surface temperature distribution $t=1 \mathrm{~s}$.

Based on the performed simulations, calculations and obtained results, the following conclusions can be drawn:

- Burner response time regarding heat transfer is $200 \mathrm{~s}$.

- Transient mantle temperature difference through its thickness is negligible from the stress-strain standpoint.

- Use of propane should be avoided at low thermal powers due to very high mantle temperature.

- Mantle temperatures are substantially lower when using methane due to lower methane flame velocity.

- The burner (appliance) switch-off procedure should include an increasing of burner power for about $200 \mathrm{~s}$, in order to decrease mantle temperature, after the flow should be cut-off.

\section{REFERENCES}

[1] Amelija, Đ., et al., The Effect of Pollutant Emission From District Heating System on the Correlation Between Air Quality and Health Risk, Thermal Science 15 (2011) 2, pp. 293-310.

[2] Raleigh, R., Premix Burners - Technology \& Engineering Challenge, National Technical Conference ASGE, Las Vegas, Nev. USA, 2008.

[3] Timothy, W., John, Z., Burner Technology For Single Digit NOx Emissions in Boiler Applications, CIBO NOx Control XIV Conference, San Diego, CA. USA, 2000.

[4] Joanes, H., The Application of Combustion Principles to Domestic Gas Burners Design, British Gas, Taylor \& Francies e-Library, 2005.

[5] Gunter, B., et al., Gas Burner Technology \& Gas Burner Design for Application, National Technical Conference ASGE, Las Vegas, Nev. USA, 2011.

[6] Feng-Guo, L., et al., On Optimal Design and Experimental Validation of Household Appliance Burner of Low Pollutant Emission, Energy Conversion and Management 76 (2013), pp.837-845.

[7] Andreini, A., et al., Numerical Analysis of a Low NOx Partially Premixed Burner for Industrial Gas Turbine Application, Energy Procedia 45 (2014), pp. 1382-1391.

[8] Fluent 6.1, User's Guide, Fluent Inc. 2005

[9] Westbrook, C., Dryer, F., Simplified Reaction Mechanism for the Oxidation of Hydrocarbon Fuels in Flames, Combustion Science and Technology 27 (1981), pp. 31-43

\section{ПРЕНОС ТОПЛОТЕ И ТЕРМОМЕХАНИЧКО ПОНАШАЊЕ АТМОСМОСФЕРСКОГ ГОРИОНИКА КУЋНЕ ГАСНЕ ГРЕЈАЛИЦЕ}

\section{В. Фотев, М. Динуловић}

Рад излаже реализовану 3D CFD симулацију фазе паљења гасног горионика са циљем одређивања максималне температурске разлике која у њему изазива максималне термичке напоне. Процес је нестационаран. Симулације је реализована за минималну снагу јер је тај случај критичан. 